\title{
Contours of a 'Post-Critical' Cartography-A Contribution to the Dissemination of Sociological Cartographic Research
}

\author{
Olaf Kühne $e^{1}$
}

Received: 29 April 2021 / Accepted: 4 June 2021 / Published online: 12 June 2021

(c) The Author(s) 2021

\begin{abstract}
Since the 1980s, 'critical cartography' has been developing. Its merits lie in its awareness of the socially constructed nature of cartographic representations, the power relations involved, and the process-bound nature of cartographic practices. The 'post-critical' cartography proposed here takes up these merits but does so without following the categorical rejection of positivist 'traditional' cartography or the moral demarcation of what can and cannot be represented as well as the subordination of theories to the 'critical' paradigm. Instead, the 'post-critical' approach relies on the struggle for suitable theoretical frameworks - the normative reference horizon within the endeavor of cartography is the enhancement of life chances. In this respect, the prefix 'post' refers not only to a temporal 'after', but also to the perpetuation of central concerns of 'critical' cartography, simultaneously freeing it from such limitations.
\end{abstract}

Keywords Post critical cartography · Critical cartography · Critical geography · Constructivism · Traditional cartography · Positivist cartography

\section{Konturen einer 'post-kritischen' Kartographie - Ein Beitrag zur Ausdifferenzierung sozialwissenschaftlichkartographischer Forschung}

\section{Zusammenfassung}

Seit den 1980er Jahren wurde die ,kritische Kartographie' entwickelt. Ihre Verdienste liegen in der Bewusstmachung der sozialen Konstruiertheit kartographischer Darstellungen, der damit verbundenen Machtbeziehungen sowie der Prozessgebundenheit kartographischer Praxen. Diese Verdienste greift die hier vorgeschlagene ,post-kritische' Kartographie auf, ohne jedoch der kategorischen Ablehnung der positivistischen ,traditionellen' Kartographie, der moralischen Demarkation des Darstellbaren und Nicht-Darstellbaren sowie der Unterordnung von Theorien unter das ,kritische' Paradigma zu folgen. Stattdessen setzt der , post-kritische' Ansatz auf das Ringen um taugliche theoretische Rahmen - normativer Bezugshorizont des Kartographie-Machens ist die Steigerung von Lebenschancen. Insofern bezieht sich das Präfix ,post' nicht nur auf ein zeitliches nach, sondern auch auf die Perpetuierung zentraler Anliegen der ,kritischen’ Kartographie, befreit sie jedoch von ihren Einschränkungen.

\section{Introduction}

When considering current topics in the context of cartographic representations, five main areas become apparent (Crampton and Krygier 2005; Dickmann 2018; Dickmann and Zehner 2001; Keil et al. 2020; Monmonier 1985):

Olaf Kühne

olaf.kuehne@uni-tuebingen.de

1 Eberhard Karls Universitat Tübingen, Tübingen, Germany
1. Initially, addressing technical issues, from projections to geographic information systems to the integration of augmented and virtual reality. 
2. Second, issues of (innovative) designs, especially in thematic maps, often in combination with the use of the Internet.

3. Subsequently, research on effects of cartographic representations or the use of these results for the communication of spatial information.

4. Additionally, availing opportunities to involve people without specialized training in the generation of cartographic representations.

5. Concluding, critical cartography.

Theoretical framings are rarely explicit in the first four cases (cartography didactics is an exception in parts; for example, Traun et al. 2013), while they mostly (implicitly) follow a positivist worldview. Critical cartography explicitly sets itself apart from this using-expressly social science oriented-constructivist perspectives, most recently also more-than-representational approaches (Glasze 2014). In contrast, other social science approaches that do not explicitly embrace a critical approach are far less present (Edler et al. 2018; Kitchin and Dodge 2007; MacEachren 2004).

The intentions of this paper are, starting from a brief characterization of the positions of critical cartography, to acknowledge their merits for the development of research, while also elaborating their worldview-related limitations for cartographic research. Starting from a research perspective that assumes a maximization of individual life chances in the sense of Dahrendorf $(1979,2007)$ and is oriented towards reflecting the perspective of Popper's (2011[1947]) principle of open society and science, a further aim is to appreciate 'traditional' as well as 'critical' cartographies and to develop contours outlining 'post-critical' cartographies, illustrates by two brief case studies.

\section{Critical Cartography-An Overview}

In the 1980 s, criticism of the positivist and technically oriented paradigm of cartography formed; after all, 'traditional' cartography understood maps as technically mediated and, by means of intersubjective valid rules, a sign-based representation of the world. Instead, building on the classic works of the emerging critical cartography (Harley 1989; Wood and Fels 1986), maps were interpreted as expressions of social and political interests, which in turn were not revealed, but-intentionally or unintentionally-rather implicitly inscribed. Uncovering these implicit interests becomes the task of critical cartography. This uncovering of (implicit) power interests, especially political and economic ones, is linked to an emancipatory claim to wrest the power to produce and interpret maps from the hands of technocratic experts (i.e. 'traditional cartographers') and to democratize it, i.e., to also involve those in the production of maps who have so far been denied access to it (by the 'technocratic experts' in particular, by societal power relations in general; e.g. in: Crampton and Krygier 2005; Glasze 2014; Harley 1989). Critical cartography's understanding of 'critique' formulates itself in distinction to Kant's (1959[1781]) understanding of critique as transcendental self-examination of reason, which delineates (Greek krínein, to distinguish, to draw boundaries) the limits of the scope and validity of its epistemic, moral, and esthetic judgments by regressively interrogating those judgments for the conditions of their possibility, each of which sets the appropriate limits on those judgments. Rather, the conception of critique is based on the view of the 'Frankfurt School' which, drawing on Karl Marx and Sigmund Freud, claims to expose the non-obvious power and domination structures of society (Horkheimer and Adorno 1969), for "the facts that the senses feed us are socially preformed in two ways: by the historical character of the perceived object and the historical character of the perceiving organ" (Horkheimer 1977[1937], p. 17). One source of critical cartography emerges from Foucault's (2012[1985]) analyses of power. The latter rejects the notion of a centered, hierarchically constructed power structure in favor of a notion that power is omnipresent and inherent in every social relationship. Currently, this perspective has been extended to include discourse-theoretical as well as more-than-representational approaches (assemblage theory, actor-network theory), each with a focus on the study of power relations (Glasze et al. 2021). Accordingly, critical cartography's critique is no longer directed solely at the object of the map (more generally: cartographic representation), but also at the practices of map production and use (Crampton 2003; Turner 2006). In this context, the focus is less on economic (capitalism and neoliberalism critique) than on political-administrative practices of cartography (in accordance with the institutional ties)—somewhat eccentrically to the otherwise usual pattern of interpretation of critical research. Recently, however, companies that provide or use cartographic information (such as Google or Facebook) have also become the focus of criticism; in this respect, the classic pattern of the critique of capitalism is updated here.

Central elements of critical cartography can be briefly summarized: (1) the social production of maps, (2) 'traditional cartographies' serve to perpetuate power relations, (3) practices of the 'traditional' production of maps must be deconstructed, (4) (critical) cartography has the task of contributing to the 'decolonization of the lifeworld' (Habermas 1981) through the systemic. In this respect, (element 5 ), hopes are placed in the development of 'neogeography' (Turner 2006), as a 'more democratic cartography', although here again the danger of appropriation or predetermination of neo-cartographers by profit-oriented companies as well as the perpetuation of 'traditional' interpretations of the world is seen, which in turn is to be counteracted by 
'critical cartographic education' (Crampton 2009; Glasze 2009; Glasze et al. 2021; Kim 2015). In addition, a practice of artistic creation of cartographic media is also seen as having emancipatory significance, after all, it could contribute to overcoming 'traditional positivist' cartography (Crampton and Krygier 2005).

\section{A Criticism of Critical Cartography}

Critical cartography has made a central contribution to bringing the social production of maps, their power-binding nature, as well as the technology-relatedness of cartography and its positivist worldview into the focus of scientific interest. Thus, the thematic field incorporating 'map', 'cartography', 'cartographic practices', etc., has become connectable for current research in social and cultural sciences. However, this establishment of connectivity is imbued with some secondary consequences, which are to be dealt with in the following.

Despite the borrowings from more-than-representational approaches as well as the connection to postmodern approaches in spatial research (Harvey 1989, 1996; Soja 1989), critical cartography is dominated by dichotomous thinking, especially in the demarcation of "critical and traditional science' within the tradition of the Frankfurt School (Horkheimer 1977[1937]), in addition to between experts (who are concerned with securing their power) and laypeople (who are deprived of their rights to independent representation of the world by the experts' interpretive sovereignty). This thinking in dichotomies can be understood as a legacy of dialectical thinking, although as an outcome of the expansion of education (formal) or almost constant availability of knowledge on the Internet, these dichotomies have at least become differentiated (Dahrendorf 1968; Müller 1998). This dichotomous thinking is also reinforced by the construction of 'false consciousness', already present in Karl Marx and Friedrich Engels, which supports the existing power relations (for example: Euchner et al. 2015). These dichotomizations are also connected with hierarchizations: 'critical' is superordinated to 'traditional' science/cartography, the interests of the 'ruled' to those of the 'rulers', i.e., the experts, both are normatively and morally chargedfollowing the special idea of emancipation. Consequently, 'traditional experts', here of cartography, are subordinated in a double sense, once as bearers of 'false consciousness', such as a 'scientistic worldview' and as 'status-securing experts' and pathologized accordingly (Grau 2017; Kühne et al. 2021), whereby they are not considered equal partners in discourse, but at best as objects of critical research (which has also evoked attempts at mediation: Thatcher et al. 2016). However, not only are 'traditional' cartographers subordinated to 'critical cartographers', current theoretical approaches from the various varieties of constructivism to actor-network theory are also understood as profitable under 'critical framing' alone (more generally in relation to the critical view: Belina 2013).

The content focus of critical cartography is directed at (unintended) secondary consequences of cartographic work: the intended consequences were initially directed towards spatial orientation and a synthetic understanding of spatial contexts. The fact that social conventions are created, updated and perpetuated in this process, which are inherent to power relations, is to be addressed, to enable 'underpowered people' (Paris 2005) to articulate and implement their own needs; however, the fundamental critique of 'positivist' cartography that is put forward does not seem to be very pragmatic (even 'revolutionary elites' are dependent on the function of basic infrastructures that are based on 'traditional cartography').

The claim to decipher the power relations lying behind things, in this case, cartographic representations, has something of essentialist 'Wesensbetrachtung' (beingness). At this point, the Freudian claim of the Frankfurt School becomes clear. Although the borrowings of critical cartography from a Marxian historicism have become indirect, a complete renunciation of it meant a lack of direction in emancipatory endeavors, a direct reference meant dealing with the totalitarian implications of, in this instance, a Marxist utopia, for one thing, and the predictions that did not occur or social developments that were not foreseen (fascism, emancipation of the working class without revolution) (Dahrendorf 1971; Popper 1965, 2011[1947]). In the face of these dilemmas, critical cartography's desire to 'democratize' cartography must also be questioned; on the one hand, an immediacy of the 'authentic' is assumed, beyond expertocratic constraints; on the other hand, nonexperts also exhibit a 'false consciousness' (among other things, as a result of subjugation in 'ideological state apparatuses'; Althusser 1977), as the current strongly polarized disputes over interpretive sovereignties in social media make clear (Nagle 2017; Wagner 2019). In turn, the generation of the prosumer that accompanies Web 2.0 mapping poses significant challenges to an approach strongly oriented toward dualistic worldviews (Schlottmann 2013).

Cartographic empowerment is not only connected with the visualization of current ('traditional') patterns of interpretation and valuation, but also with the creation of a 'correct consciousness'. This in turn is collectively oriented, in the sense of a 'cooperative mapping', the innovation possibilities of individual cartographic references to the world are largely excluded (limited in the field of art). Following the understanding of emancipative critical cartography outlined above, it also becomes clear which cartographic appropriations are discursively excluded: those that are expressions of a 'false consciousness' (especially a positivist approach) 
or are likely to solidify inequalities of power (from Mercator projections, the centering of maps on a particular continent, mostly Europe, to those whose signatures make interpretations possible in the direction of overvaluing and undervaluing collectivities, excluding elements of the world from cartographic representation). This considerably limits the range of what is (morally) acceptable in cartographic representations, both in terms of content and in terms of those so engaged (for a general discussion: Kersting 2009).

\section{Contours of a 'Post-Critical' Cartography}

The focus of critical cartography on the (mostly) unintended side-effects of doing cartography correspondingly produces, if pursued with all consistency, (unintended) side-effects that go hand in hand with the renunciation of positivistically founded cartography. In this respect, the cartography is designed following a manner that takes the critique of 'traditional' cartography seriously, is grounded in social science, but does not 'throw out the baby with the bathwater'. To this end, a theoretical basis is chosen that is less prone to moralization and being pathologized (for more detail, see Berr and Kühne 2019), one that is grounded in Karl Popper's ideas on the open society and science, and Ralf Dahrendorf's on life chances.

\subsection{An Alternative Point of Reference for Framing Social Science: Life Chances}

Central to the development of the most suitable solutions for future scientific, in particular, and social developments, in general, for Karl Popper is the possibility of having as many options as possible, which are then tested for their suitability, and mostly discarded (Popper 1959, 2011[1947]), because: "Sure knowledge is denied us. Our knowledge is a critical guessing; a web of hypotheses; a tissue of conjectures" (Popper 1989, p. XXV). This means: neither should contingent considerations (if they are compatible with human dignity) be excluded (morally) a priori, before they could be tested for their fitness, nor is there a preconceived future development of society (as suggested by historical materialism with the classless society). This means: "History has neither a priori nor even a posteriori meaning" (Dahrendorf 1979, p. 24), from which Dahrendorf-following Popper-derives the necessity to give history a meaning in a pragmatic perspective of purpose, if we want to do so and also identify it as such a pragmatic purpose (see also: Thies 2021). For Dahrendorf (1979, p. 26), this purpose lies in "creating more life chances for more people." By life chances, Dahrendorf (2007, p. 44) understands "in the first place-chances of choice, options. They require two things, entitlements to participation and an offer of activities and goods to choose from," whereby the aforementioned opportunities for choice must be connected to meaning. His understanding of chance follows Weber (1972[1922]) in that he conceives of it, on the one hand, as a "structurally based [...] probability of behavior" (Dahrendorf 1979, p. 98), and, on the other hand, "as something that the individual can have, something as a chance of satisfying interests" (Dahrendorf 1979, p. 98). Life chances are dependent on social contexts; they are "opportunities for individual growth, for the realization of abilities, desires, and hopes, and these opportunities are provided by social conditions" (Dahrendorf 1979, p. 50). That conflicts arise in the pursuit of maximizing individual life chances is 'normal' for Ralf Dahrendorf (as it was for Marx, but Dahrendorf, like Popper, rejects revolutionary eruptions because they involve bloodshed). However, an essential prerequisite for conflicts to be productive, not destructive, is that their normality be acknowledged, that the parties to the conflict recognize each other's position as legitimate, that is, recognize each other as equal parties in the effort to settle the conflict, and that they abide by the rules of the conflict settlement procedure (Dahrendorf 1972, 1994; for more detail on Dahrendorf's conflict theory, see Brüsemeister 2007; Kühne and Leonardi 2020).

\subsection{Starting Points of a 'Post-Critical' Cartography}

That critical cartography with its pathologization of traditional cartography, as well as the subordination of alternative theoretical approaches to its own paradigm, does not follow such considerations became clear from the aforementioned. Alternative interpretations of the world (here in relation to cartography) are left with two alternatives, either assimilation or exposure to moral discredit (if they become too present for the strategy of ignoring; on this: Weichhart 2014). These two options result—as Popper (2011[1947]) already stated in his 'open society' - from the idea that non-Marxist science has not seen through the boundedness of its thinking in class interest. Nearly seven decades later, Strenger (2015, p. 41) places this position of one's own moral superiority in a more general context: "The left had now seen the light and moved to relentlessly indict the corruptness of the West from a Marxist perspective". Thus also the 'bourgeois' science, to which also the 'positivistic' cartography is attributed.

A post-critical cartography takes up the concerns of critical cartography, such as the socially manufactured nature of maps, viewing cartography as a process, the power immanence of cartographic practices as well as the empowerment of non-experts for cartographic activities, but without drawing moral demarcation lines between the representable and the non-representable, without a moral devaluation of perspectives not their own or their subordination to one's own theoretical-worldview framework. Here it follows Popper's dictum for an open science (and society). Which theoretical 
(and methodological) approaches prove suitable for which questions is dependent upon the questions, not on a moral preselection. This also means that several 'medium-range theories' (Merton 1968[1949]) are (or can be) suitable for interpreting any given spatial and social phenomena. After all, individual, social, and material worlds differ markedly, and the relations between these worlds also shape themselves in complex ways (Kühne 2020; Popper 1979; Popper and Eccles 1977; Weichhart 1999) and, for all their tendency toward abstraction, are always bound not to the individual alone, but to the individual in his or her physicality (Kühne 2020; Schurr and Weichhart 2020; Weichhart 1993). This has a consequence: processes in the material world are to be treated differently than those in the social or individual world. Thus, social practices involving spatial references can also be framed with Bourdieu, power relations with Popitz, social construction processes with Berger and Luckmann, the manifold relations between society, technology, and matter can be framed on the basis of Science, Technology, and Society (STS) studies or actor-network theory (exemplary: Harvey 2000; Hubbard and Kitchin 2010), without necessarily having to resort to a superstructure via the 'critical' theory offered in (neo-)Marxist interpretation.

Such a diversity of perspectives on cartographic representations, of their conceptions, productions, effects and-here the legacy of 'critical cartography' becomes clear-requires, following Korf (2021), 'cosmopolitan' spatial scientists. Scholars, in other words, who move in different theoretical and disciplinary, but also linguistic contexts and thus (can and want to) cross borders. These border crossers should then take on the function of a 'translation' between these theoretical and disciplinary, but also linguistic contexts. A form of science, in other words, that is not about moral superiority and subordination, but the struggle to find suitable perspectives and representations of (spatial) phenomena. Here, Karl Popper's 'spotlight theory' (Popper 2011[1947]) can be updated, according to which theoretical perspectives (metaphorically considered as spotlights) are only able to illuminate certain parts of a research object, while others remain in the shadows, which in turn can be illuminated by other theories (spotlights).

The meaning of 'traditional' cartography is also to be seen in this sense: it emerged because of the challenge to find one's way in the world beyond one's own immediate visual space. The often used dictum that maps produce what they show is accordingly-exclusivistically presented-at least a one-sided interpretation of the relationship between material world and map: "Map information can certainly be interpreted as information about an area; at the latest when we miss an intended target, we are taught that maps are more and should be more than constructs that produce images of the world" (Krämer 2012, p. 154). Thus, cartography initially has a background of lifeworld pragmatism.
Cartography became a science through the standardization of lifeworld concepts of action, which on the one hand made these norms available independently of the concrete situation, and on the other hand made pre-scientific knowledge discursive (general Gethmann 1991; Janich 2004). Socially, it is the result of social differentiations and professionalization (Sofsky 2007), in the sense of a coping with complexity that gave itself its own rules and norms. While this was associated with a concentration of power as a side-effect, it also means the relief of the rest of society from the constraint of having to constantly recreate spatial representations individually or supra-individually; in this respect, it contributes to the maximization of life chances, as it thus creates temporal free spaces that would otherwise have been taken up for spatial orientation.

A 'post-critical' cartography does not try to dissolve the polarity between expert access and the rest of society. This polarity is inevitable and necessary in a society based on the division of labor and differentiation. To take two extreme examples, few people would rely on an Internet tutorial to operate on a brain tumor any more than they would to navigate a ship. If science does not want to be understood as a pure end, in itself, of scientists who are removed from the everyday world and who limit themselves to dealing with self-generated problems or questions, then its purpose is precisely to have a knowledge advantage over lifeworld skills and over the non-expertise of lay people in order-I will come back to this later-to increase their chances in life. Sciences, like cartography here, arise from the disturbances in the everyday world, for instance by illness or the need to reliably return to the starting point of the path at the end of the day. If the relationship were symmetrical, doctors, architects, scientists, as well as critical cartographers and so on would be superfluous, with all the consequences of a social dedifferentiation, which would mostly lie in a drastic shortening of life expectancy, an effective destruction of life chances. A 'post-critical' cartography is rather oriented towards whether the expression of expert knowledge expands or restricts life chances. Cartographic education in this sense is not understood as 'collective identity formation of the dominated', but as a process of forming individual capabilities, for maximizing life chances in relation to dealing with or constructing spaces (following Nussbaum 2009; Sen 1984). The fact that this always takes place in the context of power and conflict relations results from the socialization of human beings (Dahrendorf 1972; Paris 2005). The challenge consists in the regulation of conflicts and the transition from undifferentiated power to rule-bound domination (Dahrendorf 1972). In this respect, 'traditional cartography' can also be understood as an element of this process, since maps are not only used to exercise power in an undifferentiated way, but access to and the ability to read 
maps enable the verification of power relations (see, for example, Kaufmann 2005).

\subsection{Two Brief Case Studies for Illustration}

In the following, I will use two case studies to illustrate how approaches of 'traditional', 'critical', and 'post-critical' cartography differ, and how Ralf Dahrendorf's 'life-chances approach' is suitable for arriving at assessments from the practice of map-making. The first case study is the zoning plan (german: Flächennutzungsplan), the second is the engagement with intersections of social, economic, political, and ethnic polarization in Baton Rouge, Louisiana.

Zoning plan (Flächennutzungsplan): In German spatial planning, the zoning plan represents an instrument based on the German Building Code (german: Baugesetzbuch) in which an intended physical-spatial structure of a community is represented textually and cartographically (Mitschang 2018). From the perspective of 'traditional' cartography, it is the area-, angle-, and length-true depiction of a physical-spatial state desired by planners using standardized signatures (according to the notation symbol act; german: Planzeichenverordnung). This cartographic representation reverses the procedural direction of cartographic work, since it is not a material-spatial distribution that is represented, but the representation conversely the cartographic representation is the basis for material-spatial distributions. From the perspective of 'critical' cartography, the zoning plan can be described as an expression of the domination of politics through the inscription of economic interests mediated by expertocratic mechanisms (see e.g.: Neutze 1988). From a 'post-critical' perspective, the zoning plan is a the cartographic result of a process of negotiation in which different social interests are expressed in processes of negotiation between individuals, culminating in a cartographic representation as the basis for modifications of material space. The associated processes and structural manifestations can be examined on different theoretical and methodological bases and are to be (normatively) aligned with the guiding principle of maximizing individual life chances of people living in the future. This leads to the next case study.

The Inequality of Life Chances in Baton Rouge: This case study draws on extensive research presented in detail elsewhere (Kühne and Jenal 2020a, b, 2021), to the extent that I present a quintessence here regarding the relationship between cartography and the life chances approach. Baton Rouge, the capital of Louisiana, is among the most polarized metropolitan areas in the United States in terms of ethnicity, availability of economic, social, and cultural capital (in Bourdieu's 2005[1983] sense). A spatial concentration of African American population with low endowment of these capitals is found northeast of Downtown, east of the EXXON refinery. This area is also characterized by few institutions of higher education (such as high schools) as well as few locations where healthy food can be purchased (referred to as the food desert). The cartographic translation of this spatial distribution reveals a spatial structure that can be described (as a construct!) as a 'triangle of reduced life-chances' (as well as high vulnerability). A statement derived from the use of the methods of 'traditional' cartography. From Ralf Dahrendorf's approach of 'maximizing individual life chances', in turn, starting points can be derived (e.g. for politics and administration), which do not merely aim at achieving formal, but substantial equality of chances, without merely criticizing the current socio-spatial conditions or longing for utopian conditions of a more egalitarian—and thus, according to Dahrendorf $(1972,1994)$, also innovationless-society.

\section{Conclusion}

'Critical' cartography exhibits an asymmetrical relationship to collateral consequences: while it strongly focuses on the secondary consequences of 'traditional' cartography and derives far-reaching consequences, up to the rejection of a 'positivist' cartography, it is relatively insensitive to the secondary consequences of this derivation. 'Postcritical' cartographies (plural because of contingency sensitivity) take essential content of 'critical' cartography and its critique seriously, but rather than seeking to reconfigure cartography along the prevention of its collateral consequences (which in turn would come with the side consequence of reducing life chances), it is secondaryconsequence sensitive cartography. This means that cartographic representation is to be pragmatically aligned with the primary use, but potential collateral consequences are considered and weighed and justified against the purpose of the cartographic representation. It also becomes clear that cartographic representations are always individual constructions of the world with recourse to social rules and norms, which can be technical, moral, political, etc., thus always tied to power or domination. Thus, they represent an element of managing and coping with complexity. Following Kitchin/Dodge (2007), this kind of 'doing cartography' is a contingency-sensitive approach to the world, not an approach that-as critical cartography suggests-excludes interpretations and perspectives or allows them only if they can be placed in a 'critical framework'. A 'post-critical' approach to cartographic representations is open to different theoretical and methodological approaches; the standard of evaluation is the suitability for certain questions, not moral or political expediency. If only one approach to the world, in this case, a 'critical' 
one, is accepted as legitimate, it runs the risk of becoming a creed, which in turn endangers the freedom of scientific knowledge-and the step to 'conspiracy theory' is not far away, as Popper (2011[1947]) has already stated.

The widespread criticism of official statistics for cultivating 'dominance knowledge' must be put into perspective-at least in Germany - since they now make their geodata freely available (Edler and Dickmann 2019) and thus leave them to an interested public for further use. Even commercial developers publish their source codes, for example of the 'Unreal Engine', whereby considerable progress could be made in research, for example, by integrating geodata into virtual realities (VR), which also shows great potentials for spatial research in social science (Edler et al. 2019, 2020). At the same time, a relativization of dichotomous interpretative schemes, in the sense of a 'post-critical cartography', seems to be warranted.

The fact, in 'post-critical' cartographies, that the merits of a 'traditional' cartography are appreciated does not mean that the limits of the positivist approach are emphasized; what is (in large parts) an appropriate framework for the capture of the material world reaches its limits when it comes to individual and social constructions of the world. Also, thinking in dichotomies, of an either-or, which is also expressed in the transfer of the paradigm to Geographic Information Systems (GIS), seems less adequate in the face of a world (also material) characterized by hybridities; here, a greater sensitivity to transitional areas and edges is called for (Ipsen 2006), which in turn should be expressed in the enforcement of a hybriditysensitive signature language. Again, the question to be addressed is to what extent technical standards (here GIS), with their tendency to generalize their logics (Harvey and Chrisman 1998), contribute to an expansion of life chances or a reduction of life chances, and in what contexts. This is an example of the extent to which 'doing cartography' has become in need of justification. If this justification is understood not as a burden but as an envisioning of one's own contextualization, this can also be understood as a liberating act in dealing with conventions (even if the result is following conventions; see also Gryl and Jekel 2012). Also in this sense, the practice of cartography can contribute to increasing individual life chances, what was implied in the case studies (especially on Baton Rouge).

Finally, the prefix of the 'post-critical' cartographies should be outlined: 'post' also means a temporal 'after', in the sense of the succession of an exclusivist thinking, it means above all a taking up of central thoughts (social construction, power-binding nature) of the 'critical cartography', even if the consequences are different. In this context, Kant's understanding of 'critique' is used in recourse to the Greek sense of the word, i.e., in the sense of separating, distinguishing, and judging, in that an analysis of the present or emerging cartographic representations is followed by a review of their (intended) consequences and (unintended) side-effects, which then forms the basis of an evaluation against the background of different theoretical perspectives.

Funding Open Access funding enabled and organized by Projekt DEAL.

Open Access This article is licensed under a Creative Commons Attribution 4.0 International License, which permits use, sharing, adaptation, distribution and reproduction in any medium or format, as long as you give appropriate credit to the original author(s) and the source, provide a link to the Creative Commons licence, and indicate if changes were made. The images or other third party material in this article are included in the article's Creative Commons licence, unless indicated otherwise in a credit line to the material. If material is not included in the article's Creative Commons licence and your intended use is not permitted by statutory regulation or exceeds the permitted use, you will need to obtain permission directly from the copyright holder. To view a copy of this licence, visit http://creativecommons.org/licenses/by/4.0/.

\section{References}

Althusser L (1977) Ideologie und ideologische Staatsapparate: Aufsätze zur marxistischen Theorie. VSA Verlag für das Studium der Arbeiterbewegung, Hamburg, Berlin

Belina B (2013) Raum: Zu den Grundlagen eines historisch-geographischen Materialismus. Westfälisches Dampfboot, Münster

Berr K, Kühne O (2019) Moral und Ethik von Landschaft. In: Kühne O, Weber F, Berr K, Jenal C (Hrsg) Handbuch Landschaft. Springer VS, Wiesbaden, pp 351-365

Bourdieu P (2005[1983]) Ökonomisches Kapital—Kulturelles Kapital-Soziales Kapital. In: Bourdieu P (Hrsg) Die verborgenen Mechanismen der Macht. VSA, Hamburg, pp 49-80

Brüsemeister T (2007) Der moderne soziale Konflikt zwischen Unterklassen und Mehrheitsklasse-Ralf Dahrendorfs Diagnose der Bürgergesellschaft. In: Schimank U, Volkmann U (Hrsg) Soziologische Gegenwartsdiagnosen I. Eine Bestandsaufnahme. VS Verlag für Sozialwissenschaften, Wiesbaden, pp 227-238

Crampton JW (2003) The political mapping of cyberspace. The University of Chicago Press, Chicago

Crampton JW (2009) Cartography: maps 2.0. Progr Hum Geogr 33(1):91-100

Crampton J, Krygier J (2005) An introduction to critical cartography. ACME Int J Crit Geogr 4(1):11-33

Dahrendorf R (1968) Bildung ist Bürgerrecht: Plädoyer für eine aktive Bildungspolitik. Christian Wegner, Hamburg

Dahrendorf R (1971) Die Idee des Gerechten im Denken von Karl Marx. Verlag für Literatur und Zeitgeschehen, Hannover

Dahrendorf R (1972) Konflikt und Freiheit: Auf dem Weg zur Dienstklassengesellschaft. Piper, München

Dahrendorf R (1979) Lebenschancen: Anläufe zur sozialen und politischen Theorie. Suhrkamp, Frankfurt (Main)

Dahrendorf R (1994) Der moderne soziale Konflikt: Essay zur Politik der Freiheit. Deutscher Taschenbuch Verlag, München

Dahrendorf R (2007) Auf der Suche nach einer neuen Ordnung: Vorlesungen zur Politik der Freiheit im 21. Jahrhundert. C. H. Beck, München

Dickmann F (2018) Kartographie. Westermann, Braunschweig

Dickmann F, Zehner K (2001) Computerkartographie und GIS. Westermann, Braunschweig 
Edler D, Dickmann F (2019) Landschaft im amtlichen Geoinformationswesen. In: Kühne O, Weber F, Berr K, Jenal C (Hrsg) Handbuch Landschaft. Springer VS, Wiesbaden, pp 507-515

Edler D, Kühne O, Jenal C, Vetter M, Dickmann F (2018) Potenziale der Raumvisualisierung in Virtual Reality (VR) für die sozialkonstruktivistische Landschaftsforschung. KN J Cartogr Geogr Inf 68(5):245-254

Edler D, Keil J, Wiedenlübbert T, Sossna M, Kühne O, Dickmann F (2019) Immersive VR experience of redeveloped post-industrial sites: the example of "Zeche Holland" in Bochum-Wattenscheid. KN J Cartogr Geogr Inf 38(3):1-18

Edler D, Keil J, Dickmann F (2020) From Na Pali to Earth-an 'unreal' engine for modern geodata? In: Edler D, Jenal C, Kühne O (Hrsg) Modern approaches to the visualization of landscapes. Springer VS, Wiesbaden, pp 279-291

Euchner W, Stegmann FJ, Langhorst P, Jähnichen T, Friedrich N (2015) Geschichte der sozialen Ideen in Deutschland: Sozialismus-Katholische Soziallehre-Protestantische Sozialethik: Ein Handbuch. Springer-Verlag, Wiesbaden

Foucault M (2012[1985]) Discipline and punish: the birth of the prison. Knopf Doubleday Publishing Group, New York

Gethmann CF (Hrsg) (1991) Lebenswelt und Wissenschaft: Studien zum Verhältnis von Phänomenologie und Wissenschaftstheorie. Bouvier, Bonn

Glasze G (2009) Kritische Kartographie. Geogr Z 97(4):181-191

Glasze G (2014) Sozialwissenschaftliche Kartographie-, GIS- und Geoweb-Forschung. Kartogr Nachrichten 64(3):123-129

Glasze G, Bittner C, Michel B, Strüver A (2021) 18 Ein diskurstheoretisch informierter Blick auf Karten und Kartographie. In: Glasze G, Mattissek A (Hrsg) Handbuch Diskurs und Raum. Theorien und Methoden für die Humangeographie sowie die sozial- und kulturwissenschaftliche Raumforschung. TranscriptVerlag, Bielefeld, pp 405-416

Grau A (2017) Hypermoral: Die neue Lust an der Empörung. Claudius, München

Gryl I, Jekel T (2012) Re-centring geoinformation in secondary education: toward a spatial citizenship approach. Cartogr Int J Geogr Inf Geovisualization 47(1):18-28

Habermas J (1981) Theorie des kommunikativen Handelns. Suhrkamp, Frankfurt (Main)

Harley JB (1989) Deconstructing the map. Cartogr Int J Geogr Inf Geovisualization 26(2): 1-20

Harvey D (1989) The condition of postmodernity: an enquiry into the origins of cultural change. Blackwell, Oxford

Harvey D (1996) Justice, nature and the geography of difference. Blackwell, Malden

Harvey F (2000) The social construction of geographical information systems. Int J Geogr Inf Sci 14(8):711-713

Harvey F, Chrisman NR (1998) Boundary objects and the social construction of GIS technology. Environ Plan A Econ Space 30(9):1683-1694

Horkheimer M (1977[1937]) Traditionelle und kritsiche Theorie: Fünf Aufsätze. Fischer Wissenschaft, Frankfurt (Main)

Horkheimer M, Adorno TW (1969) Dialektik der Aufklärung: Philosophische Fragmente. Fischer, Frankfurt (Main)

Hubbard P, Kitchin R (2010) Introduction: why key thinkers? In: Hubbard P, Kitchin R (eds) Key thinkers on space and place. SAGE, London, pp 1-17

Ipsen D (2006) Ort und Landschaft. VS Verlag für Sozialwissenschaften, Wiesbaden

Janich P (2004) Prototheorie. In: Mittelstraß J (Hrsg) Enzyklopädie Philosophie und Wissenschaftstheorie. J. B. Metzler, Stuttgart, pp 382-383

Kant I (1959[1781]) Kritik der reinen Vernunft. Felix Meiner Verlag, Hamburg
Kaufmann S (2005) Soziologie der Landschaft. VS Verlag für Sozialwissenschaften, Wiesbaden

Keil J, Korte A, Ratmer A, Edler D, Dickmann F (2020) Augmented reality (AR) and spatial cognition: effects of holographic grids on distance estimation and location memory in a 3D indoor scenario. PFG J Photogram Remote Sens Geoinf Sci 88(2):165-172

Kersting W (2009) Verteidigung des Liberalismus. Murmann, Hamburg

Kim AM (2015) Critical cartography 2.0: From "participatory mapping" to authored visualizations of power and people. Landsc Urban Plan 142:215-225

Kitchin R, Dodge M (2007) Rethinking maps. Prog Hum Geogr 31(3):331-344

Korf B (2021) 'German Theory': on cosmopolitan geographies, counterfactual intellectual histories and the (non) travel of a 'German Foucault'. Environ Plan D Soc Space 0263775821989697. https://doi.org/10.1177/026377758219896 97

Krämer S (2012) Karten erzeugen doch Welten, oder? Soz Syst $18(1-2): 153-167$

Kühne O (2020) Landscape conflicts: a theoretical approach based on the three worlds theory of Karl Popper and the conflict theory of Ralf Dahrendorf, illustrated by the example of the energy system transformation in Germany. Sustainability 12(17):1-20

Kühne O, Jenal C (2020a) Baton Rouge - the multivillage metropolis: a neopragmatic landscape biographical approach on spatial pastiches, hybridization, and differentiation. Springer VS, Wiesbaden

Kühne O, Jenal C (2020b) Baton Rouge (Louisiana): on the importance of thematic cartography for 'Neopragmatic Horizontal Geography'. KN J Cartogr Geogr Inf 71(1):23-31

Kühne O, Jenal C (2021) Baton Rouge-a neopragmatic regional geographic approach. Urban Sci 5(1):1-17

Kühne O, Leonardi L (2020) Ralf Dahrendorf: between social theory and political practice. Palgrave Macmillan, London

Kühne O, Berr K, Schuster K, Jenal C (2021) Freiheit und Landschaft: Auf der Suche nach Lebenschancen mit Ralf Dahrendorf. Springer, Wiesbaden

MacEachren AM (2004) How maps work: representation, visualization and design. Guilford Press, New York

Merton RK (1968[1949]) Social theory and social structure. Free Press, New York

Mitschang S (2018) Flächennutzungsplan. Handwörterbuch der Stadt- und Raumentwicklung. ARL-Akademie für Raumforschung und Landesplanung, ALR, Hannover, pp 687-696

Monmonier MS (1985) Technological transition in cartography. University of Wisconsin Press, Madison

Müller W (1998) Erwartete und unerwartete Folgen der Bildungsexpansion. Köl Z Soziol Sozialpsychol Sonderhefte 38:81-112

Nagle A (2017) Kill all normies: the online culture wars from Tumblr and 4 chan to the alt-right and Trump. Zero Books, Winchester, UK

Neutze M (1988) Planning as urban management: a critical assessment. Urban Research Unit, Research School of Social Sciences, Australian National University, Canberra

Nussbaum MC (2009) Frontiers of justice: disability, nationality, species membership. Harvard University Press, Cambridge, London

Paris R (2005) Normale macht: soziologische essays. UVK Verlagsgesellschaft, Konstanz

Popper KR (1959) The logic of scientific discovery. Harper \& Row, New York

Popper KR (1965) Das Elend des Historizismus. Mohr Siebeck, Tübingen 
Popper KR (1979) Three worlds: tanner lecture, Michigan, April 7, 1978. Michigan Q Rev (1):141-167

Popper KR (1989) Logik der Forschung. Mohr Siebeck, Tübingen

Popper KR (2011[1947]) The open society and its enemies. Routledge, Abingdon

Popper KR, Eccles JC (1977) Das Ich und sein Gehirn. Piper, München

Schlottmann A (2013) Visuelle prosumtion im web2.0: Das Ende des kritischen Konstruktivismus oder seine praktische Konsequenz? In: Gryl I, Nehrdich T, Vogler R (Hrsg) geo@web. Medium, Räumlichkeit und geographische Bildung. Springer VS, Wiesbaden, pp 93-110

Schurr C, Weichhart P (2020) From margin to center? Theoretische Aufbrüche in der Geographie seit Kiel 1969. Geogr Helv 75(2):53-67

Sen A (1984) Resources, values and development. Blackwell, Oxford Sofsky W (2007) Verteidigung des Privaten: Eine Streitschrift. Beck, München

Soja EW (1989) Postmodern geographies: the reassertion of space in critical social theory. Verso, London

Strenger C (2015) Zivilisierte Verachtung. Eine Anleitung zur Verteidigung unserer Freiheit. Suhrkamp, Berlin

Thatcher J, Bergmann L, Ricker B, Rose-Redwood R, O'Sullivan D, Barnes TJ, Barnesmoore LR, Imaoka LB, Burns R, Cinnamon J, Dalton CM, Davis C, Dunn S, Harvey F, Jung J-K, Kersten E, Knigge L, Lally N, Lin W, Mahmoudi D, Martin M, Payne W, Sheikh A, Shelton T, Sheppard E, Strother CW, Tarr A, Wilson
MW, Young JC (2016) Revisiting critical GIS. Environ Plan A Econ Space 48(5):815-824

Thies C (2021) Geschichte. de Gruyter, Berlin

Traun C, Jekel T, Loidl M, Vogler R, Ferber N, Gryl I (2013) Neue Forschungsansätze der Kartographie und ihr Potential für den Unterricht. GW Unterricht 129(1):5-17

Turner A (2006) Introduction to neogeography. O'Reilly Media, Sebastopol

Wagner E (2019) Intimisierte Öffentlichkeiten: Pöbeleien, Shitstorms und Emotionen auf Facebook. Transcript Verlag, Bielefeld

Weber M (1972[1922]) Wirtschaft und Gesellschaft: Grundriss der verstehenden Soziologie. J. C. B. Mohr (Paul Siebeck), Tübingen

Weichhart P (1993) How does the person fit into the human ecological triangle? From dualism to duality: the transactional worldview. In: Steiner D, Nauser M (eds) Human ecology. Fragments of anti-fragmentary views of the world. Routledge, London, pp 103-124

Weichhart P (1999) Die Räume zwischen den Welten und die Welt der Räume. In: Meusburger P (Hrsg) Handlungszentrierte Sozialgeographie. Benno Werlens Entwurf in kritischer Diskussion. Steiner-Verlag, Stuttgart, pp 67-94

Weichhart P (2014) Etikettenschwindel? Ein missverständlicher Titel für ein spannendes Buch. Berichte Geogr Landeskunde 88(1):79-81

Wood D, Fels J (1986) Design on signs/myth and meaning in maps. Cartogr Int J Geogr Inf Geovisualization 23(3):54-103 